\title{
TINJAUAN YURIDIS DALAM BUKTI HUKUM KONSUMEN DALAM MAKANAN HALAL
}

\section{JURIDICIAL REVIEW IN CONSUMER LAW EVIDENCE IN HALAL FOOD}

\author{
Jacobus Jopie Gilalo, Adi \\ Sulistiyono, Burhanudin \\ Harahap
}

\author{
Program Doktor Fakultas Hukum, \\ Universitas Sebelas Maret. \\ Korespondensi : J. Jopie Gilalo, Tel. 0816764532 \\ e-mail : gilalojopie@gmail.com
}

\begin{abstract}
Jurnal Living Law, Vol. 12, No. 1 , 2020

hlm. 26-40

Abstract : Indonesia is a country with the majority Muslims in the world. As Muslims, it is obligatory to comply with religious prohibitions that must be obeyed, namely by not consuming food that are made from / have non-halal contents. Several laws, namely: Consumer Protection Act, Health Act, Food Act and Halal Product Guarantee Act are a form of legal protection for halal food products that can provide guarantees for consumption by Indonesian Muslim communities. This paper is a descriptive qualitative one that seeks to provide an overview of the problem of regulating halal food products in relation to consumer protection and legal protection of consumers in consuming halal food products. The results of this review study that the regulation of halal food products for companies or businesses that will trade their products in Indonesia based on the Halal Product Guarantee Act if related to consumer protection has provided legal certainty for the consumer community (Muslims) to consume halal food, namely by there are Halal Certification marks and Halal Labels. Likewise, several laws and regulations relating to halal food products that have been enacted provide legal protection for consumers in consuming food and beverages. Consumers must get information, safety and a sense of security for a food product that will be consumed according to their choices.
\end{abstract}

Keywords : Consumer Protection; Halal Food Products.

Abstrak : Indonesia merupakan negara dengan muslim mayoritas di dunia. Sebagai umat muslim, maka wajib untuk mematuhi larangan agama yang harus dipatuhi yaitu dengan tidak mengkonsumsi makanan dan minuman (pangan) yang berbahan/memiliki kandungan tidak halal. Beberapa undang-undang, yaitu: Undang-Undang Perlindungan Konsumen, Undang-Undang Kesehatan, UndangUndang Pangan dan Undang-Undang Jaminan Produk Halal (UUJPH) merupakan wujud perlindungan hukum terhadap produk pangan halal yang dapat memberikan jaminan untuk dikonsumsi oleh masyarakat muslim Indonesia. Tulisan ini bersifat kualitatif deskriptif yang berusaha memberikan gambaran mengenai permasalahan pengaturan produk pangan halal dalam kaitannya dengan perlindungan konsumen dan perlindungan hukum terhadap konsumen dalam mengkonsumsi produk pangan halal. Hasil dari kajian ini bahwa Pengaturan produk pangan halal terhadap perusahaan atau pelaku usaha yang akan memperdagangkan produknya di Indonesia berdasarkan UUJPH jika dikaitkan dengan perlindungan konsumen telah memberi kepastian hukum bagi masyarakat konsumen (muslim) untuk mengkonsumsi makanan halal, yaitu dengan adanya tanda Sertifikasi Halal dan Label Halal. Begitupun Beberapa peraturan perundang-undangan yang menyangkut produk pangan halal yang telah diberlakukan memberikan perlindungan hukum terhadap konsumen dalam mengkonsumsi makanan dan minuman. Konsumen harus mendapatkan informasi, keselamatan dan rasa aman atas suatu produk pangan yang akan dikonsumsinya sesuai dengan pilihannya.

Kata Kunci : Perlindungan Konsumen; Produk Pangan Halal. 


\section{PENDAHULUAN}

Manusia untuk dapat melangsungkan hidupnya memerlukan kebutuhan yang asasi, yaitu kebutuhan pangan. Kebutuhan akan pangan atau makan dan minum merupakan bahan bakar untuk bekerjanya mesin tubuh manusia. ${ }^{1}$ Seperti mesin, tubuh manusia pun membutuhkan energi untuk berfungsi. Energi ini dibutuhkan untuk bernafas, berjalan, berdiri, menggerakkan jari, dan bahkan untuk berpikir. $^{2}$

Pendefinisian makanan menurut World Health Organization (WHO) adalah semua substansi yang diperlukan tubuh, kecuali air dan obat-obatan serta substansisubstansi yang dipergunakan untuk pengobatan. $^{3}$ Makanan adalah semua bahan dalam bentuk olahan maupun bukan olahan yang dimakan oleh manusia, kecuali air dan obat-obatan, sebagaimana menurut Kementerian Kesehatan RI tahun 2003.

Pasal 1 Undang-Undang Nomor 18 Tahun 2012, menyebutkan Pangan adalah segala sesuatu yang berasal dari sumber hayati produk pertanian, perkebunan, kehutanan, perikanan, peternakan, perairan, dan air, baik yang diolah maupun tidak diolah, yang diperuntukkan sebagai makanan atau minuman bagi konsumsi manusia. Pangan dari pengertian ketentuan ini dapat diartikan sebagai bahan yang diolah menjadi produk makanan dan minuman.

Sedangkan produk menurut ketentuan Pasal 1 angka 1 Undang-Undang Nomor 33 Tahun 2014 tentang Jaminan Produk Halal (UU-JPH) adalah barang dan/atau jasa yang terkait dengan makanan, minuman, obat, kosmetik, produk kimiawi, produk biologi, produk rekayasa genatik, serta barang gunaan yang dipakai, digunakan, atau dimanfaatkan oleh masyarakat. Lebih

1 F.G. Winarno, 1993, Pangan, Gizi, Tehnologi dan Konsumen, PT. Gramedia Pusataka Utama, Jakarta, HIm. 3

2 Ibid., Hlm. 41.

${ }^{3}$ Hardinsyah \& I Dewa Nyoman Supariasa (Editor), 2016, Ilmu Gizi (Teori \& Aplikasi), Penerbit Buku Kedokteran EGC, Jakarta, HIm. 140. lanjut pada ketentuan ini pada angka 2 menyatakan bahwa Produk Halal adalah produk yang telah dinyatakan halal sesuai dengan syariat Islam.

Pengertian Pangan Halal adalah produk pangan yang sesuai dengan syariat Islam, yaitu:

a. halal dzat-nya,

b. halal cara memperolehnya,

c. halal dalam memprosesnya,

d. halal dalam penyimpanannya,

e. halal dalam pengangkutannya, dan halal dalam penyajiannya. ${ }^{4}$

Ahmad H. Sakr, ${ }^{5}$ mengatakan Pangan Halal itu adalah "There are foods that may contain certain types of ingredients extracted from Haram sources such as enzymes, lecithin, mono-and di-glycerides, glycogen, lard, shortening, whey, vitamins, minerals amino ides, fatty acids, alcohol of different natures, etc.

Maka, sebagai produk pangan halal dalam memproduksinya sebagai kegiatan atau proses menghasilkan, menyiapkan, mengolah, membuat, mengawet, mengemas, mengemas kembali, dan/atau mengubah bentuk pangan tidak tercemar dari unsur-unsur yang dapat mengharamkannya. ${ }^{6}$

Produk makanan halal adalah produk yang memenuhi syarat kehalalan sesuai dengan syariat Islam itu, yakni: ${ }^{7}$

1. Tidak mengandung babi dan bahan yang berasal dari babi.

2. Tidak mengandung bahan-bahan yang diharamkan seperti bahan-bahan yang berasal dari organ manusia, darah, kotoran, dan lain sebagainya.

4 Departemen Agama R.I., 2013, Tanya Jawab Seputar Produksi Halal, Bagian Proyek Sarana Dan Prasarana Produk Halal Direktorat Jenderal Bimbingan masyarakat Islam dan Penyelenggaraan Haji, Jakarta, Hlm. 17.

${ }^{5}$ Ahmad H. Sakr, 1996, Understanding Halal Foods \& Fallacies Facts, Foundation For Islamic Knowledge, Lombard, IL, p. 7.

6 Pasal 1 angka 6 Undang-Undang Nomor 18 Tahun 2012 tentang Pangan.

7 Departemen Agama R.I., 2008, Panduan Sertifikasi Halal, Direktorat Jenderal Bimbingan Masyarakat Islam dan Penyelenggaraaan Haji, Jakarta, HIm. 2. 
3. Semua bahan yang berasal dari hewan halal yang disembelih menurut tata cara syariat Islam.

4. Semua tempat penyimpanan, tempat penjualan, tempat pengolahan dan transportasi tidak boleh digunakan untuk babi dan/atau barang tidak halal lainnya. Jika pernah digunakan untuk babi dan/atau barang tidak halal lainnya terlebih dahulu harus dibersihkan dengan tata cara syariat Islam.

5. Semua makanan dan minuman yang tidak mengandung khamar.

Diundangkannya UU-JPH sebagai hukum positif yang mengikat kepada seluruh bangsa Indonesia atas produk halal, ${ }^{8}$ maka bagi umat Islam yang mayoritas konsumen sebanyak sekitar $88 \%$ itu telah memperoleh jaminan atas pangan halal yang beredar. ${ }^{9}$

Sebagai konsumen yang memakai setiap produk barang/jasa, ${ }^{10}$ berhak untuk mendapatkan kenyamanan, keamanan, dan keselamatan dalam mengkonsumsi

${ }^{8}$ Kementerian Agama RI, 2015, Sosialisasi UndangUndang Republik Indonesia Nomor 33 Tahun 2014 Tentang Jaminan Produk Halal, Direktorat Urusan Agama Islam Dan Pembinaan Syari'ah , Direktorat Jenderal Bimbingan Masyarakat Islam, Jakarta, Hlm. vii.

9 KN. Sofyan Hasan, 2015, Formulasi Hukum dan Pentingnya Jaminan Kepastian Hukum Produk Pangan Halal Dalam Hukum Nasional, Nurani, Vol. 15, No. 2, Hlm. 56.

10 Menurut Tim Penyusun Kamus Pusat Pembinaan dan Pengembangan Bahasa, 1988, Kamus Besar Bahasa Indonesia, Departemen Pendidikan dan Kebudayaan Republik Indonesia, pada halaman 80, mengartikan bahwa kata "barang" adalah benda umum; (segala sesuatu yang berwujud atau berjasad), cair, keras; semua alat perkakas, dan barang makanan yang berarti bahan makanan. Kata barang di sini tidak menunjukkan arti makanan untuk dikonsumsi. Begitu pula dalam Undang-Undang Perlindungan Konsumen mengartikan barang sebagai setiap benda, baik berwujud maupun tidak berwujud, baik bergerak maupun tidak bergerak, baik dapat dihabiskan maupun yang tidak dapat dihabiskan, yang dapat untuk diperdagangkan, dipakai, dipergunakan, atau dimanfaatkan oleh konsumen (Pasal 1 angka 4 Undang-Undang Perlindungan Konsumen). barang/jasa. Serta informasi yang benar, jelas, dan jujur mengenai kondisi dan jamian barang/jasa. ${ }^{11}$ Untuk makanan ditegaskan dalam Undang-Undang Kesehatan, makanan dan minuman yang dipergunakan untuk masyarakat harus didasarkan pada standar dan/atau persyaratan kesehatan. ${ }^{12}$

Selain itu, mengkonsumsi produk pangan halal menurut keyakinan agama (Islam) sesuai firman Allah SWT dalam surat Al- Baqarah/2: 168, menyebutkan: "Hai sekalian umat manusia makanlah dari apa yang ada di bumi segala yang halal dan baik (thayib), dan janganlah kalian ikut langkah-langkah syetan, karena sesungguhnya ia adalah musuh yang nyata bagi kalian". Juga demi kualitas hidup dan kehidupan, merupakan hak warga negara yang dijamin oleh Konstitusi. ${ }^{13}$

Dalam konteks di atas, berlakunya Undang-Undang Nomor 8 Tahun 1999 tentang Perlindungan Konsumen, UndangUndang Nomor 36 Tahun 2009 tentang Kesehatan, Undang-Undang Nomor 18 Tahun 2012 tentang Pangan, dan UndangUndang Nomor 33 Tahun 2014 tentang Jaminan Produk Halal, merupakan peran negara dalam memberikan perlindungan hukum secara nyata kepada warga negaranya untuk mengkonsumsi produk pangan yang halalan thoyiban. ${ }^{14}$

Namun kenyataannya banyak masalah yang berkaitan dengan perlindungan konsumen (muslim), yaitu belum adanya ketentuan yang mewajibkan setiap makanan (termasuk pula rumah makan) yang memberikan informasi tentang

11 Pasal 4 Undang-Undang Nomor 8 Tahun 1999 tentang Perlindungan Konsumen.

12 Lihat Pasal 111 Undang-Undang Nomor 36 Tahun 2009 tentang Kesehatan.

13 Pembukaan UUD 1945 Alinea IV yang menyebutkan: "Negara Indonesia melindungi segenap bangsa Indonesia dan seluruh tumpah darah Indonesia".

14 KN. Sofyan Hasan, Kepastian Hukum Sertifikasi dan Labelisasi Halal Produk Pangan, Jurnal Dinamika Hukum Vol. 14 No. 2 Mei 2014, Hlm. 228. Lihat juga: Zulham, Peran Negara dalam Perlindungan Konsumen Muslim terhadap Produk Halal, Kencana, Jakarta, 2018. 
kehalalan. $^{15}$ Begitu pula masih banyak produk-produk pangan yang dapat mengakibatkan bahaya dan kerusakan bila dikonsumsi, ${ }^{16}$ seperti: isu produk susu formula untuk bayi yang mengandung Enterobacter sakazakii (E sakazakii), ${ }^{17}$ dan masalah keharaman penyedap masakan Ajinomoto. ${ }^{18}$

Selain itu, terjadi kasus-kasus peredaran dan perdagangan daging ilegal di sebagian wilayah Jawa Barat, seperti di Bandung, Bogor, Cikampek, dan Karawang, yang mengakibatkan keresahan di masyarakat. ${ }^{19}$

Sebagai perbandingan di Amerika Serikat, $^{20}$ China, $^{21}$ dan India, ${ }^{22}$ dengan

15 Firman Tumantara Endipradja, 2016, Hukum Perlindungan Konsumen (Filosofi Perlindungan Konsumen dalam Perspektif Politik Hukum Negar Kesejahteraan), Setara Press, Malang, Hlm.13.

16 Din Syamsudin, Mengkonsumsi Halal Sesuai Dengan Fitrah Kemanusiaan, Jurnal Halal No. 110, November-Desember Th.XVII 2014, LPPOM MUI, Hlm. 30.

17 Yayasan Pengembangan Hukum Bisnis, Pertanggungjawaban Produsen Terhadap Publik, Jurnal Hukum Bisnis Volumen 30 No. 1 Tahun 2011, Jakarta, Hlm. 4.

18 KN. Sofyan Hasan (2015), Op.cit., Hlm. 55.

19

http://sehatmasakini.blogspot.co.id/2011/08/k asus-pangan-kasus-label-halal-daging.html, diakses pada tanggal 24 Pebruari 2018, jam. 13.15 WIB.

20 Michael S. Schumann, et.al., 1997, Food Safety Law, Van Nostrand Reinhold, Thomson Company, New York, meskipun di Amerika Serikat (AS) telah ada Undang-Undang Pangan (The Food Safety Act 1990), namun pada tahun 1996 (era Prisiden Bill Clinton), AS telah membentuk badan pengawasan untuk makanan dan obat-obatan sebagai akibat sering terjadinya insiden kesakitan dari anak-anak setelah akibat mengkonsumsi "Hamburgers" yang terkontanminasi oleh bahan yang tidak baik.

${ }^{21}$ Dengan jumlah penduduk sebanyak 1,344 milyar, jumlah Hui muslimnya sebanyak $2 \%$, namun pemerintah China telah memberikan suatu kebijakan dalam produk dan perdagangan yang menyangkut segmen pasar pangan halal. (lihat hasil penelitian: Zafar U. Ahmed, 2014, Consumer Behavior Dynamics of Chinese Minorities, Journal of Technology Management in China, Vol. 9 No. 1.)

22 Negara India telah menetapkan beberapa peraturan perundang-undangan yang jumlah penduduk terbanyak di dunia telah serius dalam memberikan perlindungan terhadap produk pangan, meskipun negara-negara tersebut bukan mayoritas penduduknya berkeyakinan beragama Islam, namun dalam kebijakan telah mewajibkan untuk memilih produk pangan atau makanan yang dikonsumsi harus memperhatikan produk-produk makanan yang tidak mengakibatkan bahaya serta kerusakan pada tingkat individual maupun sosial.

Sekarang ini budaya halal dalam mengkonsumsi produk yang halal, sudah bukan menjadi isu keagamaan saja tetapi telah menjadi tren global sebagai "New Global Life Style".23 Bahkan Din Syamsudin,, 24 mengatakan: "Halal sebagai gaya hidup baru yang bersifat global, dan terus diminati masyarakat internasional". Karena produksi yang halal dan thoyyib itu menunjukan kualitas pangan yang terjamin keamanan, kesehatan maupun kebaikan gizinya (safety food).

Maka perlu ketegasan dari pemerintah untuk memberi perlindungan kepada masyarakat (muslim) agar aman dan nyaman serta memberi ketenangan batin dalam mengkonsumsi setiap produk pangan yang halal. Meskipun regulasiregulasi untuk memberi perlindungan kepada masyarakat telah diwujudkan dengan Undang-undang Kesehatan, Undang-Undang Perlindungan Konsumen, Undang-Undang Pangan, dan UndangUndang Jaminan Produk Halal, namun tanpa kebijakan yang serius sebagai politic will, maka Undang-undang tersebut akan menjadi angan-angan belaka.

menyangkut perlindungan terhadap produk makanan (The Prevention of Food Adulteration Act (PFA) dan beberapa aturan-aturan yang menyangkut komodities, standar kesehatan, perlindungan konsumen, sertifikasi dan labelisasi produk pertanian, dan juga badanbadan pengawasannya. Lihat buku: $\mathrm{S} N$. Mahindru, 2000, Food Safety (A Techno-Legal Analysis), Tata McGraw-Hill Publishing Co.Ltd., New Delhi.

23 Ibid.

24 Ibid. 
Berdasarkan uraian dari latar belakang masalah tersebut di atas, dapat dirumuskan sebagai permasalahan dalam tulisan ini adalah sebagai berikut:

1. Bagaimana pengaturan produk pangan halal dalam kaitannya dengan perlindungan konsumen?

2. Bagaimana perlindungan hukum terhadap konsumen dalam mengkonsumsi produk pangan halal?

\section{METODE PENELITIAN}

Dalam melakukan penelitian, penulis menggunakan metode penelitian yuridis normatif yang didukung dari data yang diperoleh berdasarkan kepustakaan (library research) kemudian dilakukan analisis secara kualitatif yang hasilnya disajikan dalam tulisan yang bersifat deskriptif analitis terhadap keberadaan Undang-Undang yang berkaitan dengan Kesehatan, Konsumen, Pangan, dan Jaminan Produk Halal.

\section{PEMBAHASAN}

\section{A. PENGATURAN PRODUK PANGAN HALAL DALAM KAITANNYA DENGAN PERLINDUNGAN KONSUMEN.}

Pada tahun 2014, Indonesia telah melaksanakan survei konsumsi pangan dalam skala besar dengan melibatkan 33 provinsi, ratusan kecamatan dari 6.793 kecamatan, beberapa ribu kluster dari 79.075 kelurahan/desa, serta ratusan ribu individu yang ada di dalam keluarga, yang diukur asupan konsumsi makannya dengan tujuan untuk menentukan tingkat kecukupan konsumsi pangan nasional dan kelompok masyarakat serta menentukan perundang-undangan bidang pangan dan gizi. $^{25}$

Begitupun data dari produk yang terdaftar di Badan Pengawas Obat dan Makanan (BPOM) sebanyak 175.157 produk, baru sekitar 103.382 produk $(59,01 \%)$ yang telah bersertifikat halal

\footnotetext{
${ }^{25}$ Hardinsyah \& I Dewa Nyoman Supariasa, Op.cit.,
} HIm. 141 dan 143.
MUI. Selama 5 (lima) tahun, LPPOM MUI telah mengeluarkan sertifikat halal sebanyak 13.136 dari jumlah produk 155.774 yang beredar di Indonesia. ${ }^{26}$ Dari data ini tentu masih banyak produk-produk yang beredar di Indonesia belum mengantongi sertifikat halal MUI. Produk yang bersertifikat halal MUI didominasi produk-produk dari Indonesia, sebanyak $71 \%$. Menyusul China $17 \%$, Asia $4 \%$, ASEAN $4 \%$, Eropa $3 \%$, Australia $1 \%$. Meskipun produk Amerika Serikat (AS) banyak beredar di Indonesia, namun belum ada yang bersertifikat halal MUI, alias $0 \%{ }^{27}$

Selain itu, berdasarkan laporan tahunan United Nations Food and Agriculture Organization (UNFAO) terhadap keamanan pangan (safety food) yang dikonsumsi suatu negara, Indonesia menduduki ranking ke 71 dengan 50.6 persentasi dari indikator keamanan makanan yang dikonsumsi oleh masyarakatnya. ${ }^{28}$

Berarti untuk katagori perlindungan terhadap masyarakat di Indonesia dalam mengkonsumsi makanan yang aman masih belum memenuhi standar yang diharapkan terutama untuk produk pangan yang halal dan thoyib dengan melihat indikator data tersebut di atas.

Adanya Undang-Undang Kesehatan, Undang-Undang Perlindungan Konsumen, Undang-Undang Pangan dan UU-JPH adalah bentuk perlindungan hukum yang diberikan oleh negara kepada masyarakat (muslim) sebagai tujuan perlindungan terhadap konsumsi makanan sehat dan produk pangan halal yang beredar di Indonesia. Undang-Undang Perlindungan

26

https://www.hidayatullah.com/none/read/201 4/03/01/17428/mui-baru-keluarkan-13-136sertifikat-halal-dari-jumlah-155-774-produkyang-beredar.html., diakses pada tanggal 21 Januari 2018, jam. 10:58 WIB.

27 Ibid.

28 The Economist Intellegence Unit Limited, 2016, Global Food Security Index 2016: An Annual Measure of The State of Global Food Security, Sponsored by Dupont, United Nations Agriculture Organization, p. 10-11. 
Konsumen melindungi konsumen dalam bertransaksi dengan pelaku usaha dan mendorong pelaku usaha untuk bertanggung jawab, bersikap jujur dan terbuka dalam memberikan informasi yang benar berkaitan dengan produk barang (pangan) yang dipasarkannya dan juga menjamin mutu/kualitas, cara pengolahan dan akses informasi lainnya. ${ }^{29}$

Begitupun Undang-Undang Pangan dan UU-JPH, yaitu untuk menjamin terpenuhinya:

1. Hak-hak konsumen untuk merasa aman mengkonsumsi pangan dari kemungkinan cemaran biologis, kimia, dan bahan yang merugikan dan membahayakan kesehatan serta tidak bertentangan dengan agama, keyakinan dan budaya.

2. Mendapatkan kepastian hukum terhadap kehalalan suatu produk pangan halal yang dibuktikan dengan Sertifikat Halal dan Label Halal.

Bahkan Lembaga Pengkajian Pangan Obat-Obatan Dan Kosmetika Majelis Ulama Indonesia (LPPOM-MUI), sebagai lembaga yang berwenang memberikan Sertifikat Halal telah menerapkan Sistem Jaminan Halal (SJH) bagi perusahaan untuk memenuhi kriteria persyaratan Bahan Pangan Halal. ${ }^{30}$ Bahan halal harus memenuhi persyaratan umum, yaitu:

a. Bahan tidak berasal dari babi atau turunannya.

b. Bahan tidak mengandung bahan dari babi atau turunannya.

c. Bahan bukan merupakan khamr (minuman beralkohol) atau turunan khamr yang dipisahkan secara fisik.

d. Bahan tidak mengandung khamr (minuman beralkohol) atau turunan khamr yang dipisahkan secara fisik.

29 Sudjana \& Elinsantris Gultom, 2016, Rahasia Dagang Dalam Perspektif Perlindungan Konsumen, CV. Keni Media, Bandung, HIm. 75.

30 Lembaga Pengkajian Pangan Obat-Obatan Dan Kosmetika- Majelis Ulama Indonesia (LPPOMMUI), 2012, Persyaratan Bahan Pangan Halal (HAS 23201), tanpa penerbit, Hlm. 4. e. Bahan bukan merupakan darah, bangkai dan bagian dari tubuh manusia.

f. Bahan tidak mengandung darah, bangkai dan bagian dari tubuh manusia.

g. Bahan tidak boleh dihasilkan dari fasilitas produksi yang juga digunakan untuk membuat produk yang menggunakan bagi atau turunannya sebagai salah satu bahannya.

h. Bahan tidak bercampur dengan bahan haram atau najis yang dapat berasal dari bahan tambahan, bahan penolong dan fasilitas produksi.

i. Bahan yang memiliki potensi/kemungkinan diproduksi di fasilitas yang sama dengan bahan dari babi atau turunannya, harus disertai pernyataan pork free facility dan produsennya.

j. Perusahaan yang menerapkan pengkodean terhadap bahan atau produk harus dapat menjamin masih dapat ditelusuri dengan jelas, baik terhadap bahan yang digunakan, produsen maupun status halal dari masing-masing bahan. Pengkodean juga harus menjamin barang dengan kode yang sama berstatus halal yang sama. ${ }^{31}$

Wujud implementasi UU-JPH di atas merupakan bentuk dalam upaya pengaturan terhadap perlindungan kepada masyarakat (subjek hukum) serta hal-hal yang menjadi objek yang dilindungi. ${ }^{32}$ Maka perlindungan hukum terhadap konsumen muslim dalam mengkonsumsi produk pangan halal merupakan kewajiban negara untuk melindungi warganya dari konsumsi yang tidak halalan thoyiban.

Umumnya pemahaman para produsen industri pangan terhadap term halal tidak berbeda satu sama lainnya, mereka memaknai halal dalam arti pembebasan

\footnotetext{
31 Ibid.

32 Salim HS. \& Erlies Septiani Nurbani, 2013, Penerapan Teori Hukum Pada Penelitian Tesis dan Disertasi, Rajawali Press, Jakarta, Hlm. 262.
} 
pada produk dari unsur-unsur yang secara tegas di larang dalam syariat Islam. ${ }^{33}$ Tujuannya adalah agar adanya jaminan kepastian dari produsen bahwa produk pangan yang diproduksinya akan mampu membebaskan konsumen dari keraguraguan akan terdapatnya bahan-bahan yang secara syariat Islam di larang untuk dikonsumsi.

Pembebasan konsumen dari keraguan terhadap hal-hal yang mengandung unsur syubhat (belum jelas halal dan haramnya) maupun haram dibuktikan dengan sertifikasi dan label Halal. Melalui sertifikasi dan labelisasi ini merupakan intervensi negara terhadap produk pangan halal. Adanya ketentuan informasi produksi (product information regulation), ${ }^{34}$ sebagaimana disyaratkan dalam UU-JPH merupakan jaminan kehalalan suatu produk pengan dengan mengoptimalisasi perlindungan konsumen (muslim). Karena informasi produk pangan halal ini, jika ditinjau dari aspek keagamaan dan yuridis dapat sebagai hak privat warga negara sebagai individu yang berkaitan dengan moralitas dan integritas pribadinya sebagai muslim. ${ }^{35}$

Begitu pula labelasi dari suatu produk pangan (halal) dapat melindungi konsumen akan keakuratan mengenai jumlah, kualitas, dan isi produk. Labelasasi dibutuhkan agar konsumen dapat membandingkan dengan produk lainnya yang bersaing. ${ }^{36}$ Adanya label ini akan mendiskripsikan secara jelas setiap bahan

${ }^{33}$ Muhammad Ibnu Elmi As Pelu, 2009, Label HalalAntara Spritualitas Bisnis dan Komoditas Agama, madani Intrans Publishing, Malang, HIm. 34.

34 Zulham, 2013, Hukum Perlindungan Konsumen, Prenada Media Group, Jakarta, Hlm. 112-113.

35 Ibid.

36 Black's Law Dictionary mendefinisikan “Label (trademarks) is an informative display or written or graphic matter, such as a logo, title, or similiar marking, affixed to good or services to identify their source. A label may be put on the packing or container of a manufactured product, or on the packing or surface of a natural substance", Bryan A. Garner, 2010, Black Law Dictionary, Ninth Edition, West-Thomson Reuters, St. Paul, MN, p. 749 , asal yang terkandung dalam produk, termasuk bahan yang tersembunyi, seperti pengolahan, alat bantu pengolahan, dan bahan-bahan pendukung lainnya. Menurut O' Rourke dalam Zulham, ${ }^{37}$ menegaskan bahwa hukum makanan (food law) dan label makanan (food label) memainkan peranan penting dalam menyampaikan informasi kepada konsumen tentang produk pangan.

Undang-Undang Perlindungan Konsumen dan UU-JPH merupakan justifikasi bagi pelaku usaha atau produsen untuk yang wajib menciptakan kenyamanan bagi konsumen untuk menpergunakan barang atau mengkonsumsi produksinya dengan memberikan informasi yang benar, jelas dan jujur mengenai kondisi dan jaminan barang dan/atau jasa, serta memberikan penjelasan penggunaan, perbaikan, dan pemeliharaan. ${ }^{38}$ Selain kewajiban pelaku usaha atau produsen menjamin mutu barang dan/atau jasa yang diproduksi dan/atau diperdagangkan berdasarkan ketentuan standar mutu barang dan/atau jasa yang berlaku. ${ }^{39}$

Berkaitan dengan Jaminan Produk Halal, dalam Undang-Undang Perlindungan Konsumen, diatur bahwa pelaku usaha atau produsen di larang untuk tidak mengikuti ketentuan berproduksi secara halal, sebagaimana pernyataan "halal" yang dicantum dalam label. ${ }^{40}$ Karena salah satu tujuan dari perlindungan konsumen yaitu menciptakan sistem perlindungan konsumen yang mengandung unsur kepastian hukum dan keterbukaan informasi serta akses untuk mendapatkan informasi. ${ }^{41}$ Informasi merupakan hal yang penting bagi konsumen. Suatu kemasan pangan, informasi biasanya dalam bentuk

37 Zulham, Op.cit., Hlm. 115.

${ }^{38}$ Pasal 7 huruf (b) Undang-Undang Nomor 8 Tahun 1999 tentang Perlindungan Konsumen.

${ }^{39}$ Pasal 7 huruf (d) Undang-Undang Nomor 8 Tahun 1999 tentang Perlindungan Konsumen.

40 Pasal 8 huruf (h) Undang-Undang Nomor 8 Tahun 1999 tentang Perlindungan Konsumen.

41 Pasal 3 huruf (d) Undang-Undang Nomor 8 Tahun 1999 tentang Perlindungan Konsumen. 
label. ${ }^{42}$ Menurut Pasal 97 ayat (3) UndangUndang Pangan, Label dan Iklan Pangan untuk yang diperdagangkan di Indonesia, sekurang-kurangya memberikan keterangan mengenai:

a. Nama;

b. Daftar bahan yang digunakan;

c. Berat bersih atau isi bersih;

d. Nama dan alamat pihak yang memproduksi atau mengimpor;

e. Halal bagi yang dipersyaratkan;

f. Tanggal dan kode produksi;

g. Tanggal, bulan, dan tahun kedaluwarsa;

h. Nomor izin edar bagi Pangan Olahan; dan

i. Asal usul bahan pangan tertentu.

Berdasarkan keterangan label tersebut, maka konsumen akan diberi kebebasan untuk memilih apakah konsumen akan mengkonsumsi produk pangan itu. Menurut Gunawan Wijaya dan Ahmad Yani, informasi yang diberikan oleh pelaku usaha atau produsen merupakan hal penting bagi konsumen, karena melalui informasi tersebut konsumen dapat mempergunakan hak pilihnya secara benar. Hak milih tersebut merupakan hak dasar yang tidak dapat dihapuskan oleh siapapun juga.43 Dengan pencantuman label "Halal" pada kemasan pangan, maka konsumen yang akan mengkonsumsi produk pangan tersebut telah diberikan dan dilindungi haknya dalam memilih dan menentukan produk yang akan dikonsumsinya, dengan memilih produk yang mengandung bahan yang diharamkan atau lebih memilih produk pangan yang halal. ${ }^{44}$

42 Suyadi, Perlindungan Hukum Terhadap Konsumen Produk Pangan Olahan Yang Mengandung Bahan Rekaya Genetik, Jurnal Dinamika Hukum, Vol. 10 No. 1., Januari 2010, Hlm. 74.

43 Gunawan Widjaja dan Ahmad Yani, 2008, Hukum Tentang Perlindungan Konsumen, PT. Gramedia Pustaka Utama, Jakarta, Hlm. 30.

44 Kalau dihubungkan dengan Theory Planed Behaviour (TPB), merupakan teori pengujian secara psikologi dalam hubungan antara perilaku dan sikap seseorang, terutama yang didasari oleh keimanan seseorang, maka pilihan
Pelanggaran oleh pelaku usaha atau produsen terhadap kewajiban tidak memberikan informasi yang benar tentang produk pangan (halal) merupakan pelanggaran HAM karena hak atas informasi merupakan hak konsumen sebagai manusia. ${ }^{45}$ Hak tersebut dijamin oleh negara Indonesia sebagai negara kedaulatan hukum melalui UUD 1945 dan Undang-Undang Nomor 39 Tahun 1999 tentang Hak Asasi Manusia. Konsumen mendapatkan informasi yang benar tentang produk pangan halal merupakan hak hukum (privat) atau hak yang lahir dari hubungan hukum, yang dijamin oleh peraturan perundang-undangan. ${ }^{46}$ Dengan demikian, kewajiban bagi pelaku usaha memberikan informasi yang benar kepada konsumen (masyarakat) secara tidak langsung pada hakekatnya merupakan pengakuan terhadap hukum yang dibuat oleh negara yang berdaulat (souverignity) sebagai wujud negara melindungi bangsanya. Hal ini sesuai dengan tujuan negara Indonesia yang tertuang di dalam Pembukaan UUD 1945, bahwa “...melindungi segenap bangsa Indonesia...". Adanya kewajiban terhadap pelaku usaha

terhadap produk pangan ini, akan lebih dapat diterapkan pada budaya masyarakat tertentu. Lihat: Zafar U. Ahmed, 2014, Consumer Behavior Dynamic of Chinese Minorities, Journal of Technology Management in China, Vo. 9, No.1., p. 9. Atau menurut Muhammad Ibnu Elmi, tindakan memanipulasi kehalalan sama saja dengan desakralisasi makna halal. Karena mencantumkan label halal dalam kemasan produk dengan maksud mengelabui konsumen tanpa disertai bukti-bukti dan ikhtiar yang sungguh-sungguh dalam menunjukkan kebenaran dari label halal adalah sebentuk penipuan yang berujung pada 2 (dua) efek negatif bersamaan, yaitu efek konsumen dan efek bagi konsumen sendiri, yang sama-sama memiliki efek domino. Efek domino ini merupakan pemanipulasian konsep suci (sacred concept) untuk mencapai kepentingan pragmatis dan ambisi material semata adalah efek psikologis. Artinya secara psikologis produsen merasa tidak tenang jika melakukan manipulasi konsep halal (Muhammad Ibnu Elmi, Loc.cit. Hlm. 35-36).

45 Sudjana \& Elisantris Gultom, Op.cit., Hlm. 209.

46 Ibid. 
tersebut berkaitan erat dengan keselamatan dan kesehatan konsumen (rakyat) dalam mengkonsumsi produk pangan (halal) yang diterimanya sebagai upaya memberi rasa aman.

Selain itu, pengaturan ketentuan pidana dalam Undang-Undang JPH berlaku terhadap pelaku usaha yang tidak menjaga kehalalan Produk yang telah memperoleh Sertifikat Halal di pidana dengan pidana penjara paling lama 5 (lima) tahun atau pidana denda paling banyak Rp. 2.000.000.000,00 (dua miliar rupiah). ${ }^{47}$ Namun Undang-Undang ini juga memberikan perlindungan atas kerahasiaan bagi pelaku usaha agar dijaga rahasia dagangnya. Jika seseorang atau yang terlibat dalam proses JPH dengan tidak menjaganya atau membocorkannya, maka di pidana dengan pidana penjara paling lama 2 (dua) tahun atau pidana denda paling banyak Rp. 2.000.000.000,00 (dua miliar rupiah). ${ }^{48}$

Peraturan-peraturan yang mengatur tentang perlindungan konsumen terhadap produk pangan halal saat ini sudah memadai, namun agar lebih menjadi terintegrasi dalam memberi perlindungan terhadap masyarakat konsumen muslim sekiranya pensertifikasi dan pelabelan atas

47 Pasal 25 Undang-Undang Nomor 33 Tahun 2014 tentang Jaminan Produk Halal, menyebutkan: "Pelaku Usaha yang telah memperoleh Sertifikat Halal wajib: a. mencantumkan Label Halal terhadap Produk yang telah mendapat Sertifikat Halal; b. menjaga kehalalan Produk yang telah memperoleh Sertifikat Halal; c. memisahkan lokasi, tempat dan penyembelihan, alat pengolahan, penyimpanan, pengemasan, pendistribusian, penjualan, dan penyajian antara Produk Halal dan tidak halal; d. memperbarui Sertifikat Halal jika masa berlaku Sertifikat Halal berakhir; dan e. melaporkan perubahan komposisi Bahan kepada BPJPH". BPJHP adalah Badan Penyelenggara Jaminan Produk Halal, sebagai badan yang dibentuk oleh Pemerintah untuk menyelenggarakan JPH.

48 Pasal 43 Undang-Undang Nomor 33 Tahun 2014 tentang Jaminan Produk Halal, menyatakan: "Setiap orang yang terlibat dalam penyelenggaraan proses JPH wajib menjaga kerahasiaan formula yang tercantum dalam informasi yang diserahkan oleh Pelaku Usaha". produk pangan halal yang diajukan oleh produsen atau pelaku usaha yang akan diedarkan kepada konsumen, seharusnya menjadi kewajiban (mandatory) terhadap setiap pelaku usaha apa pun. Dengan demikian pengawasan terhadap produk pangan atau makanan halal menjadi kewenangan pemerintah secara mutlak. ${ }^{49}$ Ini salah satu fungsi pengawasan yang perlu dipikirkan untuk dibuat oleh pemerintah.

\section{B. PERLINDUNGAN HUKUM TERHADAP KONSUMEN DALAM MENGKONSUMSI PANGAN HALAL.}

Undang-Undang Nomor 8 Tahun 1999 tentang Perlindungan Konsumen (UndangUndang Perlindungan Konsumen) diatur terhadap pemenuhan Hak Konsumen atas informasi yang benar tentang produk barang berkaitan dengan proses produksinya. ${ }^{50}$ Hak atas informasi yang jelas, dan jujur mengenai kondisi dan jaminan barang. ${ }^{51}$ Hak atas informasi sangat penting, karena dengan tidak memadainya informasi yang disampaikan kepada konsumen, maka dapat dikatakan produk barang itu cacat produk karena informasi yang tidak memadai. ${ }^{52}$ Masyarakat pun perlu mendapatkan informasi yang jelas mengenai setiap produk pangan yang dikemas sebelum membeli dan mengkonsumsi pangan. ${ }^{53}$

Selain itu, hak konsumen untuk memperoleh kenyamanan, keamanan, dan keselamatan dalam mengkonsumsi barang sangat berkaitan dengan hak informasi

49 Vicky F. Taroreh, Kajian Hukum Perlindungan Konsumen Terhadap Produk Pangan Kadaluarsa, Program Studi Ilmu Hukum Pascasarjana Universitas Sam Ratulangi Manado, Jurnal Hukum, Vol.II/No.2/Januari-Maret /2014, diakses pada tanggal 15 Mei 2017, Jam 15.05 WIB.

${ }^{50}$ Sudjana \& Elisantris Gultom, Op.cit., Hlm. 103.

51 Pasal 4 ayat (3) Undang-Undang Nomor 8 Tahun 1999 tentang Perlindungan Konsumen.

52 Sudjana \& Elisantris Gultom, Loc.cit.

53 Lihat Penjelasan Umum Undang-Undang Nomor 18 Tahun 2012 tentang Pangan. 
itu, ${ }^{54}$ maka konsumen dapat memperoleh gambaran yang benar tentang suatu produk untuk dapat dikonsumsinya dan dapat memilih produk yang diinginkannya sesuai dengan kebutuhannya serta terhindar kerugian karena merasa nyaman, selamat, dan aman.

Begitu pula hak konsumen atas Jaminan Produk Pangan (Food Safety), 55 untuk mencegah efek buruk dari mengkonsumsi makanan dari produk pangan tersebut, maka keamanan pangan perlu diberlakukan pengawasan secara ketat atas produk pangan yang tidak layak edar. Pemenuhan hak konsumen atas informasi yang benar tentang produk pangan halal karena ketidaktahuannya terhadap produk pangan itu, disebabkan oleh beberapa faktor, yaitu:

1. Tingkat kecermatan SDM konsumen yang masih kurang memahami produkproduk makanan dan minuman kandungan olahan yang hendak dibelinya. Pada umumnya masih berorientasi pada penawaran harga murah dari pada mutu yang ditawarkan.

2. Produsen tidak menjelaskan atau memasang Label/Etiket pada setiap kemasannya, bahkan ada yang cenderung sengaja tidak mencantumkan atau mengaburkan Label/Etiket produknya.

54 Pasal 4 ayat (1) Undang-Undang Nomor 8 Tahun 1999 tentang Perlindungan Konsumen.

55 Food Safety atau keamanan pangan. Kalau di Amerika Serikat, adanya pengawasan terhadap produk-produk makan dan obat-obatan (Food and Drug Adminstrasion) yang diberlakukan dengan Food, Drug, and Cosmetic Act 1938; begitu pula adanya pengawas (agency) dari Departemen Pertanian yang bertanggung jawab terhadap pengurangan kelaparan dengan memberikan edukasi terhadap anak-anak tentang kesehatan, dan ada juga agency yang mengawasi peredaran produk pangan (Food Safety and Inspection Service) atau sejenis dengan BPOM di Indonesia. Lihat juga buku Bryan A. Gardner, 2010, Black Law Dictionary, Ninth Edition, West-Thomson Reuters, St. Paul, $\mathrm{MN}$, page. 560 .
3. Peran Kementerian Industri dan Perdagangan serta BPOM sebagai lembaga yang berwenang dan memiliki otoritas dalam pemberian izin edar pengawasan atas produk-produk tersebut masih sering kecolongan atas perilaku buruk pelaku usaha. ${ }^{56}$

sehingga produk pangan yang tidak memberikan informasi maupun tidak memasang Label/Etiket atas produk olahannya tersebut, mengakibatkan menjadi produk barang pangan yang tidak layak edar, seperti:

a. Tidak mencantumkan izin produksi/industri olahan dari lembaga/dinas terkait.

b. Tidak mencantumkan tanggal kadaluarsa/ED.

c. Tidak mengikuti ketentuan berproduksi secara "Halal".

d. Tidak memasang Label/Etiket atau menjelaskan ukuran, isi produk, komposisi, aturan pakai, tanggal pembuatan, akibat sampingan serta alamat pelaku usaha yang jelas.

e. Tidak mencantumkan informasi yang jelas berkaitan dengan importir/distributor yang bertanggung jawab atas impor produk tersebut, terutama untuk produk makanan dan minuman olehan impor. ${ }^{57}$

f. Patut diduga menggunakan penambahan zat-zat berbahaya dalam proses produksinya, misalnya menggunakan zat pewarna pakaian Rhodamin B atau pengawet makanan Bhorax atau penambahan penyedap rasa MSG. ${ }^{58}$

Dalam perdagangan bebas (free trade), keamanan pangan menjadi persyaratan penting dan bahkan tidak jarang non-tarif barrier, merupakan senjata untuk melindungi produk dalam negeri suatu

56 Sudjana \& Elisantris Gultom, Op.cit., Hlm. 112113.

57 Lihat Peraturan Menteri Perdagangan R.I. Nomor: 56/M-DAG/Per/12/2008 Tentang Tata Cara Impor.

58 Sudjana \& Elisantris Gultom, Loc.cit., Hlm. 113114. 
negara. Beberapa contoh yang berkaitan dengan food safety, yaitu:

1. Produk kerupuk udang dari Indonesia ditolak oleh Belanda akibat ditemukannya boraks sebagai bahan pengawet;

2. Minuman jus atau sirop dari Indonesia juga ditolak oleh Arab Saudi, karena terbukti mengandung zat pewarna yang terlarang;

3. Ekspor udang Indonesia ke Amerika ditolak karena mengandung bakteri salmonella yang berbahaya;

4. Indonesia memblokir produk susu dari Tiongkok, karena mengandung melamin yang dapat merusak ginjal; dan

5. Australia tidak mengimpor kacang tanah dari Indonesia, karena terkontaminasi aflatoksin (aspergillus flavus toxin). Negeri ini lebih suka mengimpor kacang tanah dari Israel yang bebas aflatoksin, meskipun berjarak jauh. ${ }^{59}$

Masalah kontaminasi bahan berbahaya menjadi senjata ampuh untuk menolak produk pangan (Halal) dari luar untuk melindungi produk dalam negeri, yang dibuktikan dengan kebenaran hasil uji laboratorium yang kompetensinya diakui agar tidak menimbulkan masalah serius dalam era perdagangan bebas yang berlaku secara global saat ini. Maka fungsi negara secara minimal yaitu menyediakan kebutuhan publik, pertahanan, hukum dan ketertiban serta manajemen makro ekonomi, kesehatan masyarakat maupun meningkatkan keadilan dan melindungi kaum miskin, sedangkan untuk secara menengah menangani persoalan-persoalan eksternal, seperti pendidikan dan perlindungan lingkungan, mengatur anti monopoli, memperbaiki kualitas informasi dan perlindungan konsumen serta memberikan jaminan/asuransi kepada

59 Badan Litbang Diklat Kementerian Agama RI, 2013, Makanan Dan Minuman Dalam Perspektif Al-Quran dan Sains, disusun oleh Lajnah Pentashihan Mushaf Al-Quran dan Lembaga Ilmu Pengetahuan Indonesia (LIPI), Jakarta, Hlm. 72. masyarakat sebagai bentuk kedaulatan negara harus mampu menciptakan peraturan perundang-undangan yang berpihak kepada rakyat. 60

Undang-Undang

Perlindungan

Konsumen diberlakukan bertujuan untuk menempatkan perlindungan konsumen ke dalam koridor sistem hukum perlindungan konsumen yang merupakan bagian dari sistem hukum nasional.61 Begitu pula dengan Undang-Undang Pangan dan Undang-Undang Jaminan Produk Halal (JPH), merupakan mandatory negara untuk melindungi rakyatnya sebagaimana amanat konstitusi. Adanya penjaminan atas hakhak dan kewajiban rakyat merupakan usaha pemerintah untuk membina, memperbaharui dan membangun politik hukum nasional yang mencerminkan semua kepentingan bersama semua kelompok, dengan menafikan pengutamaan suatu kelompok tertentu atas kelompok lain. ${ }^{2}$ Oleh karena itu, dengan UU-JPH adalah untuk menjamin setiap pemeluk agama beribadah dan menjalankan ajaran agamanya, di mana negara berkewajiban memberikan pelindungan dan jaminan tentang kehalalan Produk yang dikonsumsi dan digunakan masyarakat. Meskipun dari undang-undang yang dimaksud hanya memberikan kewenangan kepada Pemerintah melakukan pengawasan, pembinaan termasuk pemberian sanksi atas suatu pelanggaran yang dilakukan produsen yang dalam menjalankan kegiatan usahanya tidak sesuai dengan undang-undang tersebut.

Hak konsumen terhadap produk pangan di Amerika Serikat diatur dalam The Food Safety Act 1990, di mana undangundang ini merupakan perlindungan terhadap masyarakat untuk mengkonsumsi

60 Rachmad Safa'at, 2014, Rekonstruksi Politik Hukum Pangan-Dari Ketahanan Pangan Ke Kedaulatan Pangan, Universitas Brawijaya (UB) Press, Malang, Hlm. 97.

61 Firman Tumantara Endipradja, Op.cit., Hlm. 57.

62 Moh. Mahfud MD, 2010, Membangun Politik Hukum Menegakkan Konstitusi, Rajawali Press, Jakarta, Hlm. 13-16. 
makan yang aman (the safety of food). ${ }^{63}$ Undang-undang ini mengatur keselamatan, kesehatan, kualitas, label makanan, tuntutan dan sanksi bagi yang melanggarnya. Oleh karena itu, dalam setiap produk pangan dan barang yang diperdagangkan yang berlaku di Amerika Serikat, adanya standarisasi untuk food safety ini.64 Adanya beberapa aturan yang menyangkut impor makan, kepabeaan (Customs) agar barang atau makanan tidak tercermar dalam pengiriman yang semuanya dilakukan dalam pengawasan The United States Food and Drug Administrasion (FDA). ${ }^{65}$

Ditetapkannya peraturan perundangundangan tentang keamanan pangan (food safety) merupakan upaya dari setiap negara untuk melindungi warga negara yang juga sebagai konsumen dari akibat atau efek yang timbul dari mengkonsumsi makanan dan minuman yang tidak sesuai dengan kesehatan. ${ }^{66}$ Di Indonesia setelah disahkannya Undang-Undang Nomor 33 Tahun 2014 tentang Jaminan Produk Halal (UU-JPH) merupakan regulasi yang khusus untuk melindungi konsumen (muslim) untuk mendapatkan produk halal. ${ }^{67}$ Jaminan produk halal dibuktikan dengan sertifikasi halal, karena produk yang telah dinyatakan halal itu sesuai dengan syariat Islam, di mana proses produksi baik mencakup penyediaan bahan, pengolahan, penyimpanan, pengemasan, pendistribusian, penjualan dan penyajian terhadap hasil produk di jaminan kehalalannya. ${ }^{68}$

63 Malcom Leder and Peter Shears, 1992, Consumer Law, Third Edition, Pitman Publishing, London, p. 240.

64 Michael S. Schumann, et.al., 1997, Food Safety Law, Van Nostrand Reinhild, New York, p. 9.

65 Dennis Campbell, 1996, International Food and Beverage Law, Kluwer Law International, London, p. 426.

66 Ibid.

67 Zulham, 2013, Hukum Perlindungan Konsumen, Prenada Media Group, Jakarta, Hlm. 117.

68 Lihat Pasal 1, angka 2, angka 3, dan angka 5 Undang-Undang Nomor 33 Tahun 2014 tentang Jaminan Produk Halal.
Pengaturan sertifikasi dan labelisasi produk halal dalam UU-JPH yang diatur oleh Pasal 4, yaitu produk yang diperdagangkan wajib bersertifikat halal. Pasal ini menyatakan, bahwa: "Produk yang masuk, beredar, dan dipedagangkan di wilayah Indonesia wajib bersertifikat halal. Berdasarkan rumusan ini, dapat dipahami bahwa pengaturan sertifikat dan labelisasi produk halal mengandung norma mandatory, ${ }^{69}$ karena setiap produk yang diperdagangkan di Indonesia wajib bersertifikat halal, terkecuali untuk produk pangan yang berasal dari bahan yang diharamkan namun bagi pelaku usahanya diwajibkan untuk mencantumkan keterangan tidak halal pada produknya. ${ }^{70}$

Jika produk pangan yang beredar di Indonesia tanpa keterangan halal pada produk yang bersangkutan, maka perlindungan dan kepastian hukum bagi konsumen (muslim) menjadi haram untuk dikonsumsi. Indonesia hanya akan menjadi ajang dumping barang dan jasa yang tidak bermutu. ${ }^{71}$ Yang lebih mengkhawatirkan, kesejahteraan rakyat yang dicita-citakan menjadi lebih sulit terwujud. ${ }^{72}$ Pentingnya hukum perlindungan konsumen juga disadari, karena setiap konsumen (muslim) selalu memerlukan produk pangan halal yang aman bagi keselamatan dan serta jiwanya dalam beribadah. Untuk menjamin hal-hal tersebut, maka diperlukan adanya kaidah-kaidah hukum yang menjamin syarat-syarat aman setiap produk konsumen bagi konsumsi manusia yang harus dilengkapi dengan informasi yang benar, jujur dan bertanggung jawab. ${ }^{73}$ Oleh karena, pengawasan secara efektif terhadap Sistem pendaftaran yang semula dilakukan oleh BPJPH, sekiranya dapat

\footnotetext{
${ }^{69}$ Zulham, Loc.cit.

70 Pasal 26 Undang-Undang Nomor 33 Tahun 2014 tentang Jaminan Produk Halal.

71 Vicky F. Taroreh, Op.cit., Hlm. 101.

72 Sudaryatmo, 1999, Hukum \& Advokasi Konsumen, Cetakan Kedua, Citra Aditya Bakti, Bandung, Hlm. 84.

73 A. Z. Nasution, 2002, Hukum Perlindungan Konsumen: Suatu Pengantar, Diadit Media, Jakarta, Hlm. 16.
} 
langsung diselenggarakan oleh pemerintah sebagai mandatory pemberi bukti yang kompeten atas sertifikasi halal, yang sementara bagi pelaku usaha atau produsen hanya bersifat voluntary untuk mendapatkan sertifikasi itu apabila memperdagangkan produk halal.

Dengan sistem ini akan memberi paradigma kepada jaminan kepastian hukum atas hasil produksi pangan halal dan perlindungan terhadap konsumen maupun produsen selain menjadi tanggung jawab pribadi dan juga menjadi tanggung jawab pemerintah yang dijalankan oleh instansi yang diamanatkan untuk hal tersebut.

\section{KESIMPULAN}

1. Pengaturan produk pangan halal terhadap perusahaan atau pelaku usaha yang akan memperdagangkan produknya di Indonesia berdasarkan Undang-Undang Jaminan Produk Halal jika dikaitkan dengan perlindungan konsumen telah memberi kepastian hukum bagi masyarakat konsumen (muslim) untuk mengkonsumsi makanan halal, yaitu dengan adanya tanda Sertifikasi Halal dan Label Halal. Meskipun pemenuhan sertifikasi dan label dimaksud masih bersifat sukarela (voluntary) belum menjadi kewajiban (mandatory) bagi setiap perusahaan dan/atau pelaku usaha di bidang pangan atau makanan dan minuman.
2. Beberapa peraturan perundangundangan yang menyangkut produk pangan halal yang telah diberlakukan, seperti Undang-Undang Pangan dan Undang-Undang JPH telah memberikan perlindungan hukum terhadap konsumen dalam mengkonsumsi makanan dan minuman. Undangundang perlindungan konsumen telah secara jelas menentukan bahwa konsumen harus mendapatkan informasi, keselamatan dan rasa aman atas suatu produk pangan yang akan dikonsumsinya sesuai dengan pilihannya.

\section{SARAN}

1. Perlunya suatu kebijakan aturan dari pemerintah bahwa setiap produsen atau pelaku usaha di bidang pangan dan/atau makanan dan minuman di seluruh Indonesia untuk diwajibkan (mandatory) mencantumkan sertifikat maupun label halal di setiap produk pangan yang dihasilkan atau menandainya dengan label halal.

2. Untuk lebih memudahkan pengetahuan konsumen atas produk pangan halal, maka pemerintah dapat mencari suatu bentuk tanda atau semacam code pada label produk makanan itu yang bersifat simpel dan sesuai dengan budaya lokal agar mudah dikenali oleh konsumen (muslim) bahwa makanan tersebut halal untuk dikonsumsi.

\section{DAFTAR PUSTAKA}

\section{A. Buku}

Ahmad H. Sakr, 1996, Understanding Halal Foods \& Fallacies Facts, Foundation For Islamic Knowledge, Lombard, IL.

A. Z. Nasution, 2002, Hukum Perlindungan Konsumen: Suatu Pengantar, Diadit Media, Jakarta.

Badan Litbang Diklat Kementerian Agama RI, 2013, Makanan Dan Minuman Dalam Perspektif Al-Quran dan Sains, disusun oleh Lajnah Pentashihan Mushaf Al-Quran dan Lembaga Ilmu Pengetahuan Indonesia (LIPI), Jakarta. 
Departemen Agama R.I., 2008, Panduan Sertifikasi Halal, Direktorat Jenderal Bimbingan Masyarakat Islam dan Penyelenggaraaan Haji, Jakarta.

2013, Tanya Jawab Seputar Produksi Halal, Bagian Proyek Sarana Dan Prasarana Produk Halal Direktorat Jenderal Bimbingan masyarakat Islam dan Penyelenggaraan Haji, Jakarta.

Dennis Campbell, 1996, International Food and Beverage Law, Kluwer Law International, London.

F.G. Winarno, 1993, Pangan, Gizi, Tehnologi dan Konsumen, PT. Gramedia Pusataka Utama, Jakarta.

Firman Tumantara Endipradja, 2016, Hukum Perlindungan Konsumen (Filosofi Perlindungan Konsumen dalam Perspektif Politik Hukum Negar Kesejahteraan), Setara Press, Malang.

Gunawan Widjaja dan Ahmad Yani, 2008, Hukum Tentang Perlindungan Konsumen, PT. Gramedia Pustaka Utama, Jakarta.

Hardinsyah \& I Dewa Nyoman Supariasa (Editor), 2016, Ilmu Gizi (Teori \& Aplikasi), Penerbit Buku Kedokteran EGC, Jakarta.

Kementerian Agama RI, 2015, Sosialisasi Undang-Undang Republik Indonesia Nomor 33 Tahun 2014 Tentang Jaminan Produk Halal, Direktorat Urusan Agama Islam Dan Pembinaan Syari'ah , Direktorat Jenderal Bimbingan Masyarakat Islam, Jakarta.

Lembaga Pengkajian Pangan Obat-Obatan Dan Kosmetika- Majelis Ulama Indonesia (LPPOM-MUI), 2012, Persyaratan Bahan Pangan Halal (HAS 23201), tanpa penerbit.

Malcom Leder and Peter Shears, 1992, Consumer Law, Third Edition, Pitman Publishing, London.

Michael S. Schumann, et.al., 1997, Food Safety Law, Van Nostrand Reinhold, Thomson Company, New York.

Moh. Mahfud MD, 2010, Membangun Politik Hukum Menegakkan Konstitusi, Rajawali Press, Jakarta.

Muhammad Ibnu Elmi As Pelu, 2009, Label Halal-Antara Spritualitas Bisnis dan Komoditas Agama, Madani Intrans Publishing, Malang.

Rachmad Safa'at, 2014, Rekonstruksi Politik Hukum Pangan-Dari Ketahanan Pangan Ke Kedaulatan Pangan, Universitas Brawijaya (UB) Press, Malang.

Salim HS. \& Erlies Septiani Nurbani, 2013, Penerapan Teori Hukum Pada Penelitian Tesis dan Disertasi, Rajawali Press, Jakarta.

S N. Mahindru, 2000, Food Safety (A Techno-Legal Analysis), Tata McGraw-Hill Publishing Co.Ltd., New Delhi.

Sudjana \& Elinsantris Gultom, 2016, Rahasia Dagang Dalam Perspektif Perlindungan Konsumen, CV. Keni Media, Bandung.

Sudaryatmo, 1999, Hukum \& Advokasi Konsumen, Cetakan Kedua, Citra Aditya Bakti, Bandung.

The Economist Intellegence Unit Limited, 2016, Global Food Security Index 2016: An Annual Measure of The State of Global Food Security, Sponsored by Dupont, United Nations Agriculture Organization.

Zulham, 2013, Hukum Perlindungan Konsumen, Prenada Media Group, Jakarta. 


\section{B. Perundang-Undangan}

Undang-Undang Dasar Tahun 1945.

Undang-Undang Nomor 8 Tahun 1999 tentang Perlindungan Konsumen.

Undang-Undang Nomor 36 Tahun 2009 tentang Kesehatan.

Undang-Undang Nomor 18 Tahun 2012 tentang Pangan.

Undang-Undang Nomor 33 Tahun 2014 tentang Jaminan Produk Halal.

Peraturan Menteri Perdagangan R.I. Nomor: 56/M-DAG/Per/12/2008 Tentang Tata Cara Impor.

\section{Lain-Lain}

Bryan A. Garner, 2010, Black Law Dictionary, Ninth Edition, West-Thomson Reuters, St. Paul, MN.

Din Syamsudin, Mengkonsumsi Halal Sesuai Dengan Fitrah Kemanusiaan, Jurnal Halal No. 110, November-Desember Th.XVII 2014, LPPOM MUI.

https://www.hidayatullah.com/none/read/2014/03/01/17428/mui-baru-keluarkan13-136-sertifikat-halal-dari-jumlah-155-774-produk-yang-beredar.html

https://www.hidayatullah.com/none/read/2014/03/01/17428/mui-baru-keluarkan-

13-136-sertifikat-halal-dari-jumlah-155-774-produk-yang-beredar.html., diakses pada tanggal 21 Januari 2018, jam. 10:58 WIB.

http://sehatmasakini.blogspot.co.id/2011/08/kasus-pangan-kasus-label-halaldaging.html, diakses pada tanggal 24 Pebruari 2018, jam. 13.15 WIB.

KN. Sofyan Hasan, Kepastian Hukum Sertifikasi dan Labelisasi Halal Produk Pangan, Jurnal Dinamika Hukum Vol. 14 No. 2 Mei 2014.

KN. Sofyan Hasan, 2015, Formulasi Hukum dan Pentingnya Jaminan Kepastian Hukum Produk Pangan Halal Dalam Hukum Nasional, Nurani, Vol. 15, No. 2.

Suyadi, Perlindungan Hukum Terhadap Konsumen Produk Pangan Olahan Yang Mengandung Bahan Rekaya Genetik, Jurnal Dinamika Hukum, Vol. 10 No. 1., Januari 2010.

Tim Penyusun Kamus Pusat Pembinaan dan Pengembangan Bahasa, 1988, Kamus Besar Bahasa Indonesia, Departemen Pendidikan dan Kebudayaan Republik Indonesia, Jakarta.

Vicky F. Taroreh, 2014, Kajian Hukum Perlindungan Konsumen Terhadap Produk Pangan Kadaluarsa, Program Studi Ilmu Hukum Pascasarjana Universitas Sam Ratulangi Manado, Jurnal Hukum, Vol.II/No.2/Januari-Maret /2014, diakses pada tanggal 15 Mei 2017, Jam 15.05 WIB.

Yayasan Pengembangan Hukum Bisnis, Pertanggungjawaban Produsen Terhadap Publik, Jurnal Hukum Bisnis Volumen 30 No. 1 Tahun 2011, Jakarta.

Zafar U. Ahmed, 2014, Consumer Behavior Dynamics of Chinese Minorities, Journal of Technology Management in China, Vol. 9 No. 1. 